\title{
Nitro Group Reduction and Suzuki Reaction Catalyzed by Palladium Supported on Magnetic Nanoparticles Modified with Carbon Quantum Dots Generated from Glycerol and Urea
}

\author{
Mohammad Gholinejad, ${ }^{*[a]}$ Fatemeh Zareh, ${ }^{[a]}$ Carmen Nájera ${ }^{*}[\mathrm{~b}]$
}

\begin{abstract}
In this work, we use glycerol and urea as green and cheap sources of carbon quantum dots (CQD) for modifying $\mathrm{Fe}_{3} \mathrm{O}_{4}$ NPs. The obtained CQD@ $\mathrm{Fe}_{3} \mathrm{O}_{4} \mathrm{NPs}$ is used for the stabilization of palladium species and the prepared catalyst $\mathrm{Pd@CQD@} \mathrm{Fe}_{3} \mathrm{O}_{4}$ is characterized by different techniques such as TEM, SEM, XPS, XRD AAS, EDX-mapping, and VSM. This magnetic supported palladium has been applied as an efficient catalyst for the reduction of aromatic nitro compounds to primary amines at room temperature using very low palladium loading $(0.008 \mathrm{~mol} \%)$ and also for the Suzuki-Miyaura cross-coupling reaction of different aryl halides as well as for challenging heteroaryl bromides and aryl diazonium salts with arylboronic acids and with potassium phenyltrifluoroborate. This magnetically recyclable catalyst has been recovered and reused for 7 consecutive runs in the reduction of 4-nitrotoluene to $p$-toluidine and during 10 consecutive runs in the reaction of 4-iodoanisole with phenylboronic acid with small decrease of activity. The reused catalyst in the Suzuki reaction is characterized by TEM, VSM and XPS. Using different experiments such as hot filtration and poisoning tests, it has been shown that the true catalyst works under homogeneous conditions according to the release-return pathway of active $\mathrm{Pd}$ species.
\end{abstract}

\section{Introduction}

Nowadays environmental problems encourage chemists to design new reaction processes complemented with green chemistry objectives.$^{[1]}$ Along this line, recyclable heterogeneous catalysts play an important role in decreasing or eliminating chemical wastes, particular when large scale operations or industrial scales are considered. ${ }^{[2]}$ However, despite the extensive applications of heterogeneous catalysts in organic transformations, using simple methods such as filtration or centrifugation are not efficient and precise methods for separation of expensive and toxic metals such as Pd which have $<5$ ppm allowable limits in pharmaceuticals. ${ }^{[3,4]}$ On the other

[a] Dr.Mohammad Gholinejad and Fatemeh Zareh

Department of Chemistry, Institute for Advanced Studies in Basic

Sciences (IASBS), P. O. Box 45195-1159, Gavazang, Zanjan

45137-6731, Iran

E-mail: gholinejad@iasbs.ac.ir

[b] Prof. Carmen Najera

Departamento de Química Orgánica and Centro de Innovación en Química Avanzada (ORFEO-CINQA). Universidad de Alicante, Apdo. 99, E-03080-Alicante, Spain.Email:cnajera@ua.es

Supporting information for this article is given via a link at the end of the document hand, magnetic materials due to their superparamagnetic behavior and therefore easy separation from the reaction mixture, large ratio of surface area to volume and low toxicity, have been considered as a promising support for stabilization of metal catalysts. ${ }^{[5]}$

Reduction of nitro compounds to the corresponding amines is a significant chemical reaction from the industrial and academic standpoints. The resulting amines are valuable intermediates in the synthesis of different materials such as dyes, polymers, pesticides, antioxidants, drugs and agrochemicals. Different transition metals show good activities for the reduction of nitro compounds. However, Pd catalyzed nitro reductions offer high efficiency and selectivity for the formation of primary amines. ${ }^{[6]}$ Also, among vast number of reactions catalyzed by palladium, the Suzuki-Miyaura reaction, which is the cross-coupling reaction between aryl, vinyl, or alkyl halides or pseudo-halides and organoboron reagents, could be considered one of the most important methods for the formation of different types of compounds, especially biphenyls. ${ }^{[7]}$

Concerning solid supports, carbon quantum dots (CQD) are a new class of carbon-derived nano-materials with unique properties such as high solubility, photo-stability and fluorescence emitors, being considered green, non-toxic, abundant, and inexpensive materials. ${ }^{[8]}$ In the past years, CQD have been prepared using different green and cheap source such as chitosan, ${ }^{[9]}$ orange peels, ${ }^{[10]}$ coffee grounds ${ }^{[11]}$ coriander leaves, ${ }^{[12]}$ and bloomed algae. ${ }^{[13]}$ Recently, CQD were synthesized using glycerol as green solvent via a pyrolysis process and applied in cell imaging and drug release. ${ }^{[14]} \mathrm{New}$ applications of CQD were reported by Dey and coworkers as a reducing agents for the synthesis of Pd nanoparticles (NPS) and their applications as an efficient catalyst in Heck and Suzuki reactions ${ }^{[15]}$ Also, we recently reported the modification of magnetic NPS and magnesium oxide with CQD or graphene quantum dots (GQD) and their application for stabilizations of $\mathrm{Pd}$ and $\mathrm{Pd}-\mathrm{Cu}$ NPs in different cross-coupling reactions. ${ }^{[16]}$ In continuation with our interest in carbon quantum dots and magnetic palladium catalysts, herein, we wish to disclose palladium supported on magnetic NPs of $\mathrm{Fe}_{3} \mathrm{O}_{4}$ modified with nitrogen doped carbon quantum dots obtained from glycerol and urea as green and non-toxic sources. We envisaged that this material Pd@CQD@ $\mathrm{Fe}_{3} \mathrm{O}_{4} \mathrm{NPs}$ could be used as recyclable catalyst in reduction of nitroarenes and Suzuki-Miyaura reactions. 


\section{Results and Discussion}

Synthetic steps for the preparation of the catalyst are summarized in Scheme 1. The corresponding CQD were obtained by heating glycerol and urea in a Teflon autoclave at $180{ }^{\circ} \mathrm{C}$. Photoluminescence $(\mathrm{PL})$ emission study of prepared CQD showed a broad emission centered at $430 \mathrm{~nm}$ with an excitation wavelength at $350 \mathrm{~nm}$ (Figure 1), which is a characteristic sign for the formation of CQD. ${ }^{[7]}$ In the case of $\mathrm{CQD} @ \mathrm{Fe}_{3} \mathrm{O}_{4} \mathrm{NPs}$, aqueous solution of the prepared CQD was mixed with prepared $\mathrm{Fe}_{3} \mathrm{O}_{4} \mathrm{NPs}^{[17]}$ at $80{ }^{\circ} \mathrm{C}$ for $48 \mathrm{~h}$. In the final step, an aqueous solution of CQD@ $\mathrm{Fe}_{3} \mathrm{O}_{4} \mathrm{NPs}$ was treated with a sonication-assisted solution of $\mathrm{PdCl}_{2}$ under vigorous stirring conditions and the final solid Pd@CQD@ $\mathrm{Fe}_{3} \mathrm{O}_{4}$ NPs was obtained with $0.08 \mathrm{mmolg}^{-1}$ of $\mathrm{Pd}$ contents determined by atomic absorption spectroscopy (AAS)

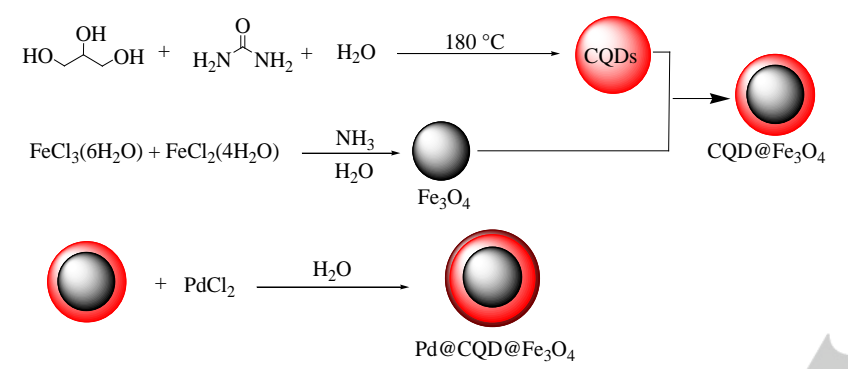

Scheme 1. Steps for the preparation of the Pd@CQD@Fe ${ }_{3} \mathrm{O}_{4}$ NPs

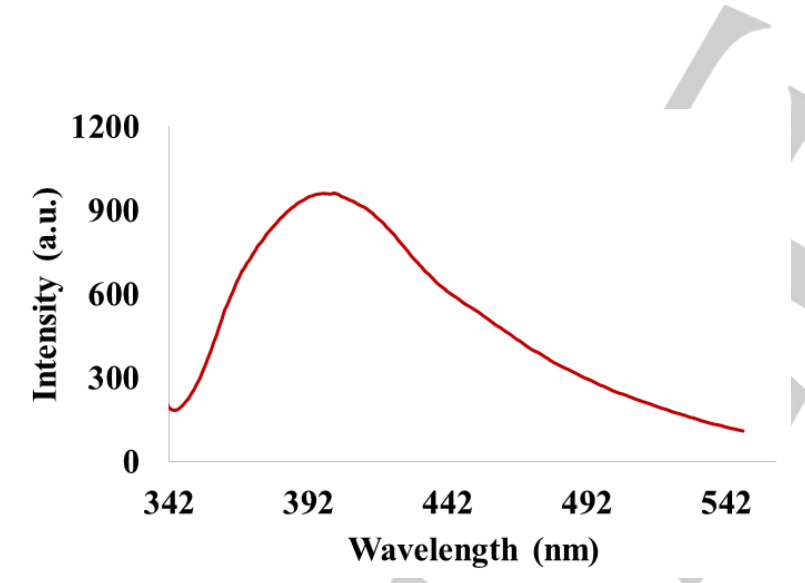

Figure 1.Fluorescence spectrum of prepared CQD from glycerol and urea

TEM image of $\mathrm{Pd@CQD@} \mathrm{Fe}_{3} \mathrm{O}_{4}$ in different magnification showed that the sample has uniform particles in 15-20 nm. Despite that $\mathrm{Pd}$ species is not visible in TEM images; very thin layer of CQD shell is detectable around the magnetic NPS (Figure 2).

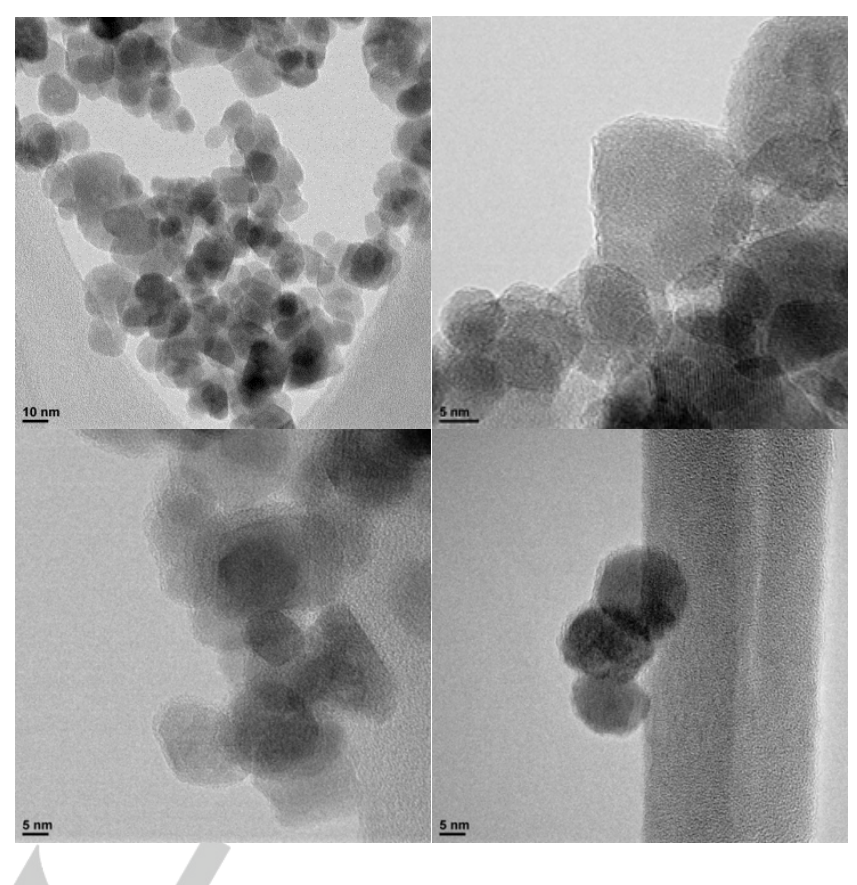

Figure2.TEM images of Pd@CQD@ $\mathrm{Fe}_{3} \mathrm{O}_{4}$ NPs in different magnifications

Also, SEM images showed presence of highly mono dispersed and uniform magnetic nanoparticles (Figure 3).

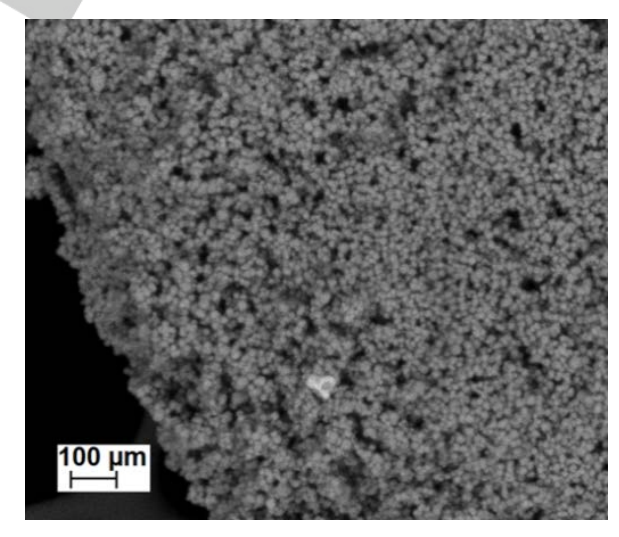

Figure 3. SEM images of Pd@CQD@ $\mathrm{Fe}_{3} \mathrm{O}_{4} \mathrm{NPs}$.

The corresponding EDS mapping images of the $\mathrm{Pd} @ \mathrm{CQD} @ \mathrm{Fe}_{3} \mathrm{O}_{4}$ indicated the presence of $\mathrm{C}, \mathrm{N}, \mathrm{Fe}$, and $\mathrm{Pd}$ in the structure (Figure 4). 


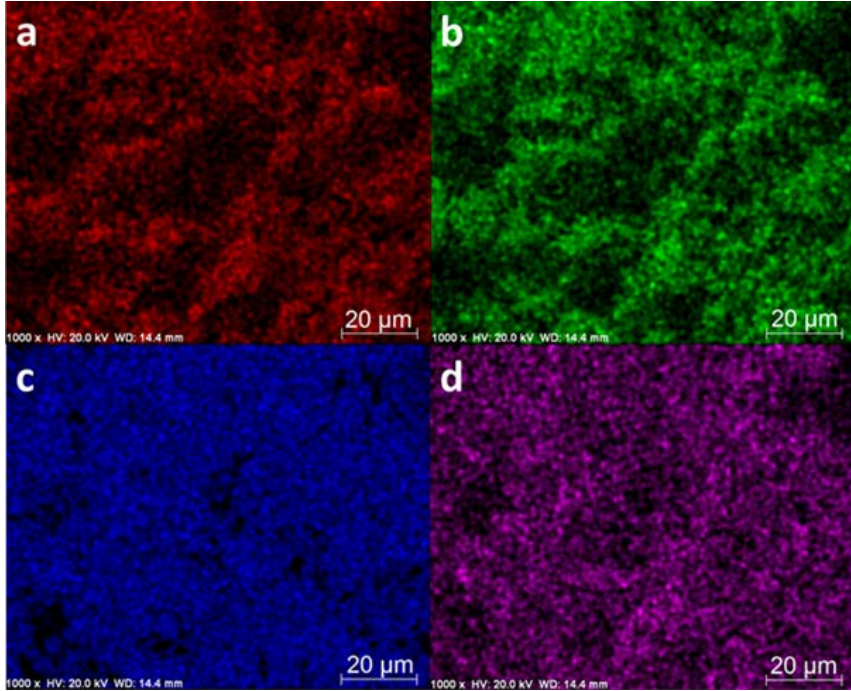

Figure 4. EDS mapping images of a) $\mathrm{C}$, b) N, c) Fe, and d) Pd

Further insight into the surface composition of the $\mathrm{Pd@CQD@Fe} \mathrm{O}_{4} \mathrm{NPs}$ was obtained from X-ray photoelectron spectroscopy (XPS). High resolution XPS of the obtained materials in $C$ 1s region confirmed the presence of carbon by appearing four peaks at 284.58, 285.3, 286.02, and $288.80 \mathrm{eV}$ correspond to $\mathrm{C}-\mathrm{C} / \mathrm{C}=\mathrm{C}, \mathrm{C}-\mathrm{N}, \mathrm{C}-\mathrm{O}$, and $\mathrm{C}=\mathrm{O}$ forms of carbon respectively (Figure 5). ${ }^{[18]}$

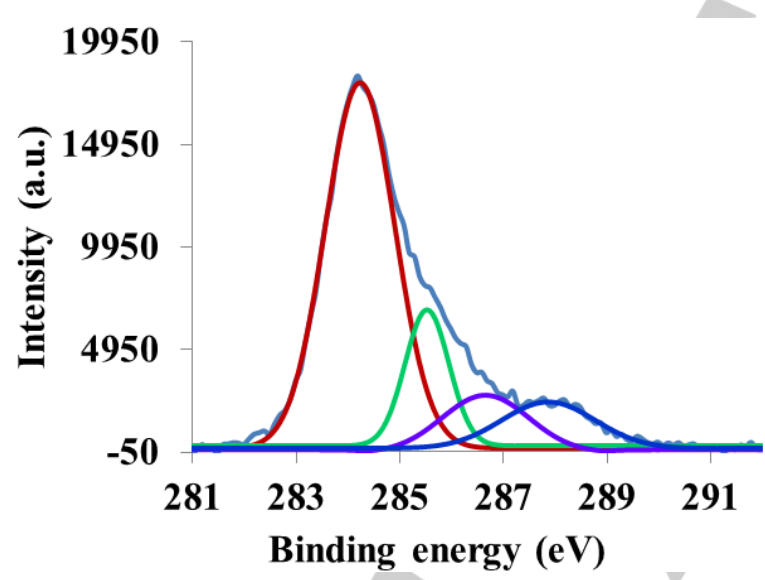

Figure 5. XPS spectrum of the Pd@CQD@ $\mathrm{Fe}_{3} \mathrm{O}_{4} \mathrm{NPs}$ in $\mathrm{C}$ 1s region.

Also, the presence of Pd in the structure was proved using XPS by studding the binding energy range of $335-342 \mathrm{eV}$ related to $P d 3 d_{5 / 2}$ and $P d 3 d_{3 / 2}$. These results showed the presence of two doublet at 335.6 and $340.8 \mathrm{eV}$ related to $\mathrm{Pd}(0)$ and peaks at 338 and $343 \mathrm{eV}$ related to $\mathrm{Pd}(\mathrm{II})$ species, respectively. ${ }^{[19,20]}$ As can be seen in Figure 6 , palladium is mainly in metallic state proving the noteworthy ability of carbon quantum dots for reducing $\mathrm{Pd}(\mathrm{II})$ to $\mathrm{Pd}(0)$. Mechanism of the metal reduction is not clear for us. However, it is believed that presence of different hydroxyl and carboxyl functionalized groups on the carbon quantum dots surface can act as reducing agents and produce metal nanoparticles. ${ }^{[15,21]}$

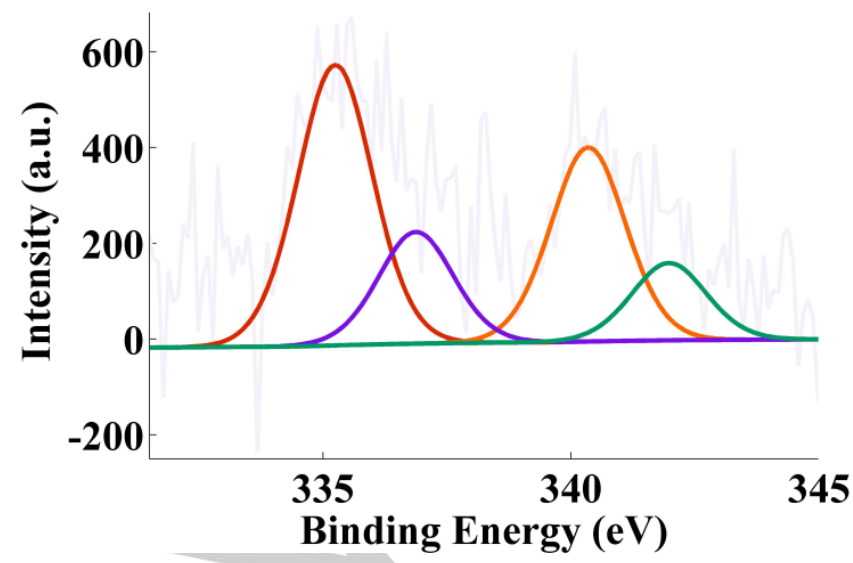

Figure 6. XPS spectrum of the Pd@CQD@ $\mathrm{Fe}_{3} \mathrm{O}_{4} \mathrm{NPs}$ in $\mathrm{C}$ 1s region in $\mathrm{Pd}$ 3d region.

X-ray powder diffraction (XRD) study of $\mathrm{Pd} @ \mathrm{CQD} @ \mathrm{Fe}_{3} \mathrm{O}_{4}$ showed 2theta values at $40.2^{\circ}, 46.7^{\circ}$ and $68.2^{\circ}$ related to (111), (200) and (220) plans of $\mathrm{Pd}(0)$ and 2 theta values at $30.1^{\circ}, 35.5^{\circ}$, $43.1^{\circ}, 53.4^{\circ}, 57.0^{\circ}$ and $62.6^{\circ}$ correspond to (210), (311), (400), (422), (511), and (440) plans of $\mathrm{Fe}_{3} \mathrm{O}_{4}$ (Figure 7). ${ }^{[2]}$

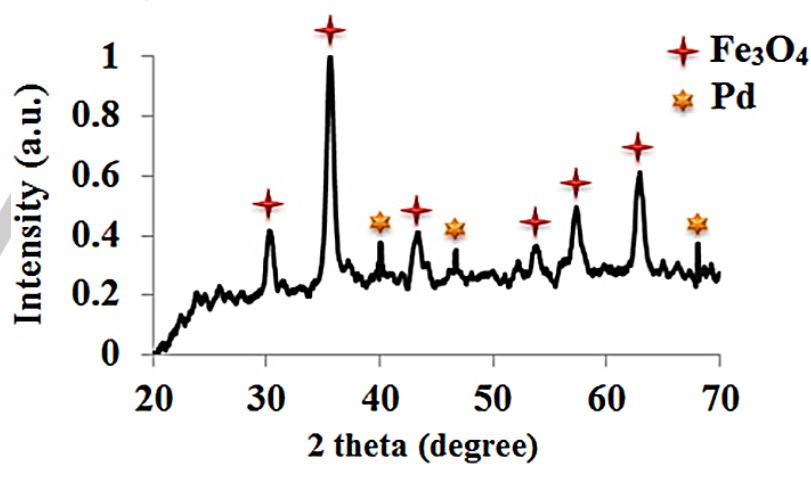

Figure 7. XRD pattern of the Pd@CQD@ $\mathrm{Fe}_{3} \mathrm{O}_{4} \mathrm{NPs}$.

The superparamagnetic property of the catalyst was confirmed using the magnetization curve $\left(74 \mathrm{emu} \mathrm{g}^{-1}\right)$, showing Zero coercivity and remanence on the magnetization loop and absence of hysteresis loop (Figure 8). 


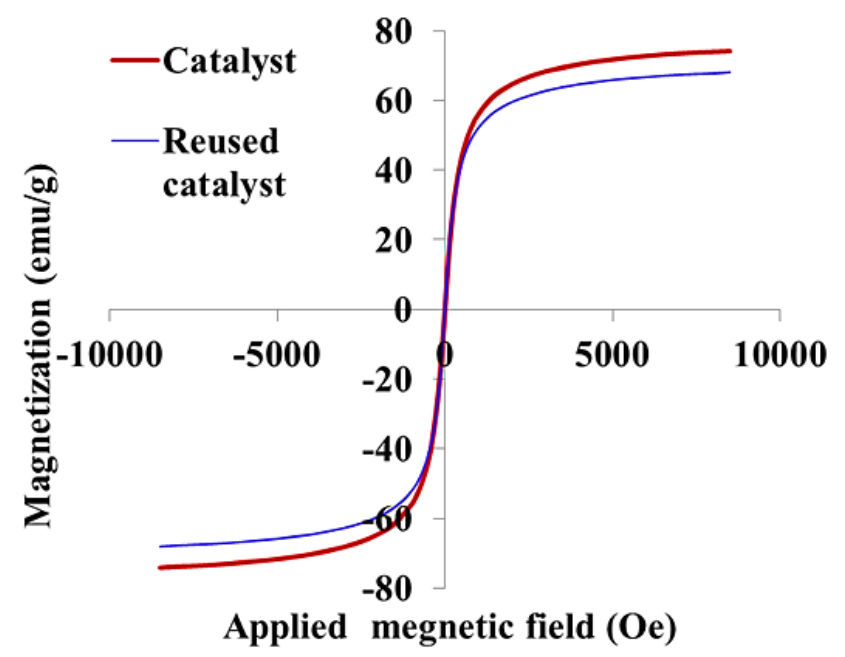

Figure 8. Magnetization curves of the Pd@CQD@ $\mathrm{Fe}_{3} \mathrm{O}_{4} \mathrm{NPs}$ and of the reused catalyst after the $3^{\text {rd }}$ run.

The nitrogen adsorption-desorption isotherms for $\mathrm{Pd@CQD@Fe} \mathrm{O}_{4}$ NPs possessed type-IV isotherms with $\mathrm{H} 3$ hysteresis loop according to the IUPAC classification and the Brunauer-Emmett-Teller (BET) surface areas of $71 \mathrm{~m}^{2} \mathrm{~g}^{-1}$ (Figure 1, ESI). The pore size distribution of the catalyst was calculated from adsorption branch of the isotherm by BarrettJoyner- Halenda $(\mathrm{BJH})$ method. A relatively narrow pore size distribution at the mean value of $r_{p}=1.64 \mathrm{~nm}$ and por valume of $\mathrm{vp}=0.45 \mathrm{~cm}^{3} \mathrm{~g}^{-1}$ in the catalyst indicate appropriate size distribution (Figure 2, ESI).

Thermal gravimetric analysis of the Pd@CQD@ $\mathrm{Fe}_{3} \mathrm{O}_{4}$ NPS showed one weight loss in $25-100{ }^{\circ} \mathrm{C}$ which is related to physisorbed water and solvents and second main weight loss between $250-340{ }^{\circ} \mathrm{C}$, which is related to the decomposition of CQD. This result confirmed thermal stability and negligible leaching of structure up to $250^{\circ} \mathrm{C}$ (Figure 9).

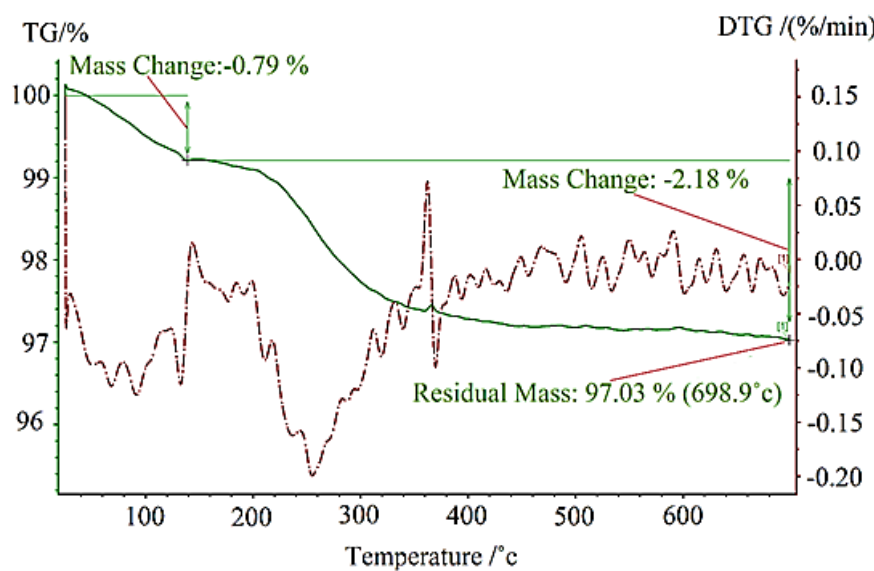

Figure 9. Thermogravimetric diagram of the Pd@CQD@ $\mathrm{Fe}_{3} \mathrm{O}_{4} \mathrm{NPs}$.
The catalytic properties of the Pd@CQD@ $@ \mathrm{Fe}_{3} \mathrm{O}_{4} \mathrm{NPs}$ were first assessed in the reduction of aromatic nitro compounds. We focused our initial investigation on the effect of various types of reducing agents and palladium amount on the reduction of nitrobenzene as a model reaction in aqueous ethanol (Table 1). Results indicated that using $\mathrm{NaBH}_{4}$ as source of hydrogen and $0.1 \mathrm{~mol} \% \mathrm{Pd}$ at room temperature, the reaction proceed well and $100 \%$ conversion of nitrobenzene to aniline was obtained (Table 1 , entry 1). Therefore, we used lower amount of $\mathrm{Pd}(0.002-0.008$ mol\%) at room temperature (Table 1, entries 2-5). Results of this study showed excellent conversion to desired product using $0.008 \mathrm{~mol} \%$ of $\mathrm{Pd}$ catalyst during $2 \mathrm{~h}$ (Table 1, entry 5). Using other hydrogen sources at different reaction conditions gave very lower yields for the reaction (Table 1, entries 6-12). Thus, we selected $\mathrm{NaBH}_{4}$ as source of hydrogen and $0.008 \mathrm{~mol} \%$ of $\mathrm{Pd}$ loading at room temperature as the best optimized reaction conditions. It is worth mentioning that $\mathrm{NaBH}_{4}$ is one the mild and efficient reducing agents for the reduction of nitro group ${ }^{[23]}$ and model reaction in the absence of $\mathrm{Pd}$ catalyst failed to proceed (Table 1, entry 13).

Table 1. Optimization of the reaction conditions for the reduction of nitrobenzene ${ }^{a}$

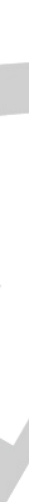

\begin{tabular}{|c|c|c|c|c|c|}
\hline Entry & $\mathrm{H}$ donor & $\mathrm{T}\left[{ }^{\circ} \mathrm{C}\right]$ & $t[h]$ & $\begin{array}{c}\text { Cat. } \\
\text { [mol\%] }\end{array}$ & yield $[\%]^{b}$ \\
\hline 1 & $\mathrm{NaBH}_{4}$ & r.t & 2 & 0.1 & 100 \\
\hline 2 & $\mathrm{NaBH}_{4}$ & r.t & 2 & 0.002 & 10 \\
\hline 3 & $\mathrm{NaBH}_{4}$ & r.t & 24 & 0.002 & 64 \\
\hline 4 & $\mathrm{NaBH}_{4}$ & r.t & 24 & 0.004 & 91 \\
\hline 5 & $\mathrm{NaBH}_{4}$ & r.t & 2 & 0.008 & 97 \\
\hline 6 & $\mathrm{NH}_{4} \mathrm{HCO}_{2}$ & 90 & 24 & 0.008 & 7 \\
\hline 7 & $\mathrm{NH}_{4} \mathrm{HCO}_{2}$ & r.t & 24 & 0.1 & 3 \\
\hline 8 & $\mathrm{~N}_{2} \mathrm{H}_{4}$ & r.t & 24 & 0.008 & 2 \\
\hline 9 & $\mathrm{~N}_{2} \mathrm{H}_{4}$ & r.t & 24 & 0.1 & 2 \\
\hline 10 & $\mathrm{HCO}_{2} \mathrm{H}$ & r.t & 24 & 0.008 & 1 \\
\hline 11 & glycerol & r.t & 24 & 0.008 & 1 \\
\hline
\end{tabular}




$\begin{array}{llllll}12 & \text { i-PrOH } & \text { r.t } & 24 & 0.008 & 0 \\ 13 & \mathrm{NaBH}_{4} & \text { r.t } & 24 & - & 0\end{array}$

[a] Reaction conditions: Nitrobenzene $(0.5 \mathrm{mmol}), \mathrm{H}$ donor $(2 \mathrm{eq})$, catalyst (see, column) and solvent ( $2 \mathrm{~mL}$ )

[b] GC yields using normalization method.

Next, the scope and limitations of this reductive methodology using a series of nitroarenes were examined (Table 2). Results of Table 2 indicated that the reduction of aromatic nitro compounds containing electron-donating groups such as Me, $\mathrm{OMe}$, and $-\mathrm{NH}_{2}$, (Table 2, entries 2-5) as well as nitroarenes having electron- withdrowing groups such as $-\mathrm{NO}_{2}, \mathrm{~F},-\mathrm{COMe}$ and $\mathrm{Br}$ proceeded well and afforded the coresponding amines in high to excellent yields (Table 2, entries 6-10). Also, reactions of nitroarenes containing 0 -substituents proceed effectively and gave amines in high to exellent yields (Table 2, entries 11-14). Finally the reduction of 2,6-dimethyl-1-nitrobenzene, as highly sterically hindered nitroarene, took place in high $91 \%$ yield giving the corresponding amine after $24 \mathrm{~h}$.

Table 2. Pd@CQD@ $\mathrm{Fe}_{3} \mathrm{O}_{4} \mathrm{NPs}$ catalyzed reduction of different nitroarene using $\mathrm{NaBH} 4$ as a hydrogen source in aqueous ethanol at room temperature

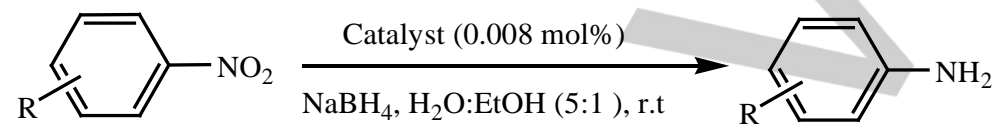

\begin{tabular}{|c|c|c|c|c|}
\hline Entry & Substrate & Product & yield (\%) & Time (h) \\
\hline 1 & & & 97 & 2 \\
\hline 2 & & & $87(100)$ & 2(4) \\
\hline 3 & & & $86(100)$ & 2(4) \\
\hline 4 & & & 93 & 4 \\
\hline 5 & & & $90(100)$ & $4(12)$ \\
\hline
\end{tabular}


<smiles>O=[N+]([O-])c1cccc([N+](=O)[O-])c1</smiles><smiles>O=[N+]([O-])c1ccc(F)cc1</smiles>

8<smiles>O=[N+]([O-])c1ccc([N+](=O)[O-])cc1</smiles><smiles>O=[N+]([O-])c1ccc(Br)cc1</smiles>

10<smiles>CC(=O)c1cccc([N+](=O)[O-])c1</smiles>

11<smiles>O=[N+]([O-])c1ccccc1Cl</smiles><smiles>Cc1ccccc1[N+](=O)[O-]</smiles>

13<smiles>CC(=O)c1ccccc1[N+](=O)[O-]</smiles><smiles>OCCO</smiles>

14<smiles>Cc1ccccc1[N+](=O)[O-]</smiles><smiles>Nc1cccc(N)c1</smiles><smiles>Nc1ccc(F)cc1</smiles><smiles>Nc1ccc(N)cc1</smiles><smiles>Nc1ccc(Br)cc1</smiles><smiles>CC(=O)c1cccc(N)c1</smiles><smiles>Cc1ccccc1N</smiles><smiles>Cc1ccccc1N</smiles> 
15<smiles>Cc1cccc(C)c1[N+](=O)[O-]</smiles><smiles>Cc1cccc(C)c1N</smiles>

91

24

[a] Reaction conditions: Nitroarene $(0.5 \mathrm{mmol})$, catalyst $(0.008 \mathrm{~mol} \% \mathrm{Pd}), \mathrm{NaBH}_{4}$ (2 equiv), $\mathrm{H}_{2} \mathrm{O}: \mathrm{EtOH}(5: 1,2 \mathrm{~mL})$ at room temperature under argon atmosphere.

[b] GC yields

In an attempt to extend the application of this catalyst,

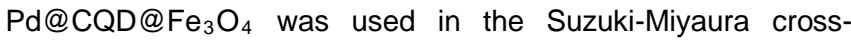
coupling reaction of aryl halides. In order to study the optimized reaction conditions, 4-bromoanisole was allowed to react with phenylboronic acid and effects of different factors such as solvent and base were considered. Results of this study indicated that using equal mixture of ethanol and water as a solvent, $t$-BuOK as a base and $0.3 \mathrm{~mol} \%$ of Pd catalyst gave the desired product in $92 \%$ yield by GC (Table 3, entry 4 ).

Table 3. Optimization of the reaction conditions using of 4-bromoanisol and phenylboronic acid catalyzed by Pd@CQD@ $\mathrm{Fe}_{3} \mathrm{O}_{4} \mathrm{NPs}^{\mathrm{a}}{ }^{2}$

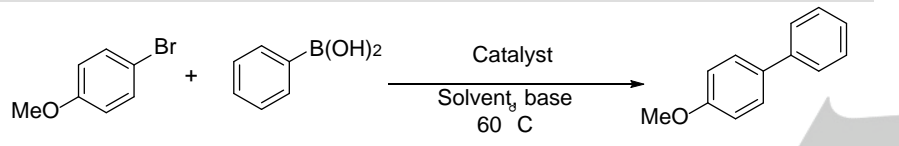

\begin{tabular}{|c|c|c|c|c|}
\hline Entry & Catalyst (mol\% Pd) & Base & Solvent & Yield $\%{ }^{b}$ \\
\hline 1 & 0.3 & $\mathrm{~K}_{2} \mathrm{CO}_{3}$ & $\mathrm{H}_{2} \mathrm{O} / \mathrm{EtOH}$ & 53 \\
\hline 2 & 0.3 & $\mathrm{~K}_{2} \mathrm{CO}_{3}$ & $\mathrm{H}_{2} \mathrm{O} / \mathrm{CH}_{3} \mathrm{CN}$ & 10 \\
\hline 3 & 0.3 & $\mathrm{NaOH}$ & O/EtO & 49 \\
\hline 4 & 0.3 & $t$-BuOK & $\mathrm{H}_{2} \mathrm{O} / \mathrm{EtOH}$ & 92 \\
\hline 5 & 0.2 & $t$-BuOK & $\mathrm{H}_{2} \mathrm{O} / \mathrm{EtOH}$ & 71 \\
\hline 6 & 0.1 & $t$-BuOK & $\mathrm{H}_{2} \mathrm{O} / \mathrm{EtOH}$ & 53 \\
\hline 7 & 0.01 & $t$-BuOK & $\mathrm{O} / \mathrm{E}$ & 7 \\
\hline 8 & 0.3 & $t$-BuOK & $\mathrm{H}_{2} \mathrm{O} / \mathrm{EtOH}$ & $15^{\mathrm{c}}$ \\
\hline 9 & 0.3 & $t$-BuOK & $\mathrm{EtOH}$ & 63 \\
\hline 10 & 0.3 & $t$-BuOK & $\mathrm{H}_{2} \mathrm{O}$ & 72 \\
\hline 11 & 0.3 & $\mathrm{NaOH}$ & $\mathrm{H}_{2} \mathrm{O}$ & 53 \\
\hline 12 & 0.3 & $\mathrm{NaOH}$ & $\mathrm{EtOH}$ & 70 \\
\hline
\end{tabular}

11

$\mathrm{NaOH}$ $\mathrm{H}_{2} \mathrm{O} / \mathrm{EtOH}$

41

[a] Reaction conditions: 4-bromoanisole $(0.5 \mathrm{mmol})$, phenylboronic acid (0.75 $\mathrm{mmol})$, base $(0.75 \mathrm{mmol})$, catalyst (see column) and solvent $(2 \mathrm{~mL})$.

[b] GC yields using normalization method.

[c] Reaction performed at $50^{\circ} \mathrm{C}$.

Using the optimized reaction conditions, Suzuki reaction of structurally different aryl halides with different arylboron compounds was studied. Reactions of aryl bromides containing electron-withdrawing groups such as $4-\mathrm{NO}_{2}, 4-\mathrm{CN}, 4-\mathrm{Cl}$, 4$\mathrm{COCH}_{3}, 4-\mathrm{CHO}$, and 3-CHO with phenylboronic acid proceeded efficiently and the desired biphenyls were obtained in high to excellent yields (Table 4, entries 1-6). Also, reactions of less reactive arylbromides containing electron-donating groups such as $-\mathrm{OH}$ and $-\mathrm{OMe}$ as well as bromobenzene and 1bromonaphthalene performed efficiently and afforded biphenyls in high to excellent yields (Table 4, entries 7-10). Reactions of challenging 2-bromopyridine and 5-bromopyrimidine as heterocyclic compounds proceeded efficiently without poising and deactivation of the catalyst by heteroatoms and afforded products in $82-90 \%$ isolated yields (Table 4, entries 11-12). Furthermore, reactions of aryl bromides with other arylboronic acids and potassium phenyltrifluoroborate gave products in high to excellent yields (Table 4, entries 13-21). Reactions of aryl chlorides under the optimized reaction conditions were sluggish; therefore different reaction conditions were studied. It has been found that using PEG200 and $\mathrm{NaOH}$ at $120^{\circ} \mathrm{C}$ are the most effective conditions for the Suzuki reaction of aryl chlorides (Table 4, entries 22-25). In addition, reactions of aryl iodides with arylboronic acids under optimized reaction conditions performed very efficiently and afford coupling products in excellent yields in less than 4 hours (Table 4, entries 26-28).

Arenediazonium salts are alternative substrates to aryl halides in different $\mathrm{Pd}$ catalyzed coupling reactions ${ }^{[24]}$ and can be easily prepared from commercially available anilines. In order to show potential activity of presented catalyst, we have studied Suzuki reaction of different aryldiazonium tetrafluoroborates with phenylboronic acid under the optimized reaction conditions. Results of this study showed formation of desired products in high to excellent yields either using electron-donating or electron-withdrawing substituents in the aryldiazonium salt (Table 4, entries 29-33). 
Table 4. The reactions of structurally different aryl halides and aryldiazonium tetrafluoroborates with arylboronic acids and potassium phenyl trifluoroborate in the presence of the catalyst Pd@CQD@ $\mathrm{Fe}_{3} \mathrm{O}_{4} \mathrm{NPs}$. ${ }^{2}$

$$
\begin{array}{lc}
\mathrm{Ar}^{1} \mathrm{X}+\mathrm{Ar}^{2} \mathrm{BR} & \text { Catalyst (0.3 mol\%) } \\
\mathrm{X}=\mathrm{Cl}, \mathrm{Br}, \mathrm{I}^{1}, \mathrm{~N}_{2}{ }^{+} \mathrm{BF}_{4}^{-} \mathrm{Ar}^{-} & t-\mathrm{BuOK}, \mathrm{EtOH}: \mathrm{H}_{2} \mathrm{O}(1: 1) \\
\mathrm{R}=(\mathrm{OH})_{2}, \mathrm{~F}_{3} \mathrm{~K} & 60-120^{\circ} \mathrm{C}
\end{array}
$$

\begin{tabular}{llll}
\hline Entry & $\operatorname{Ar}^{1}$ & $\operatorname{Ar}^{2} \mathrm{BR}$ & Time(h) \\
& & & Product \\
\hline
\end{tabular}

1<smiles>O=[N+]([O-])c1ccc(Br)cc1</smiles>

2<smiles>N#Cc1ccc(Br)cc1</smiles>

3<smiles>Clc1ccc(Br)cc1</smiles>

4<smiles>CC(=O)c1ccc(Br)cc1</smiles>

5<smiles>O=Cc1ccc(Br)cc1</smiles>

6<smiles>O=Cc1cccc(Br)c1</smiles>

7<smiles>COc1ccc(Br)cc1</smiles>

$\mathrm{PhB}(\mathrm{OH})_{2}$

$\mathrm{PhB}(\mathrm{OH})_{2}$

$\mathrm{PhB}(\mathrm{OH})_{2}$

$\mathrm{PhB}(\mathrm{OH})_{2}$

$\mathrm{PhB}(\mathrm{OH})_{2}$

$\mathrm{PhB}(\mathrm{OH})_{2}$
2<smiles>O=[N+]([O-])c1ccc(-c2ccccc2)cc1</smiles>

94<smiles>N#Cc1ccc(-c2ccccc2)cc1</smiles>

12<smiles>Clc1ccc(-c2ccccc2)cc1</smiles>

80<smiles>CC(=O)c1ccc(-c2ccccc2)cc1</smiles>

$99^{c}$

2<smiles>O=Cc1ccc(-c2ccccc2)cc1</smiles>

94

12<smiles>O=Cc1cccc(-c2ccccc2)c1</smiles>

85

12

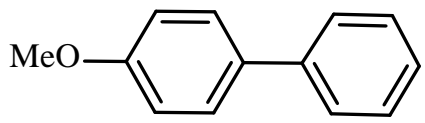


8<smiles>Oc1ccc(Br)cc1</smiles>

9<smiles>Brc1ccccc1</smiles><smiles>Brc1cccc2ccccc12</smiles>

11<smiles>Brc1ccccn1</smiles>

$\mathrm{PhB}(\mathrm{OH})_{2}$

$\mathrm{PhB}(\mathrm{OH})_{2}$

$\mathrm{PhB}(\mathrm{OH})_{2}$

10

24

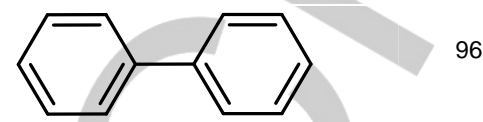

12<smiles>Oc1ccc(-c2ccccc2)cc1</smiles><smiles>Brc1cncnc1</smiles>

$\mathrm{PhB}(\mathrm{OH})_{2}$<smiles>COc1ccc(Br)cc1</smiles>

24

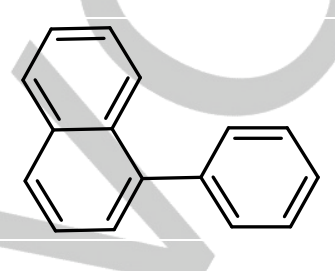

77

12<smiles>Brc1ccccc1</smiles>

14<smiles>N#Cc1ccc(Br)cc1</smiles><smiles>Oc1ccc(Cl)cc1</smiles>
24

24<smiles>Fc1cccc(-c2ccccc2)n1</smiles>

90

82<smiles>Fc1ccc(-c2cncnc2)cc1</smiles>

95<smiles>COc1ccc(-c2ccccc2)cc1</smiles>

15

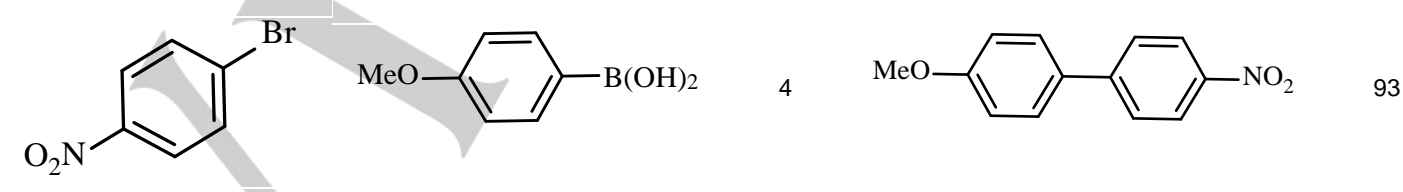

16<smiles>COc1ccc(C(O)(O)c2ccccc2)cc1</smiles>

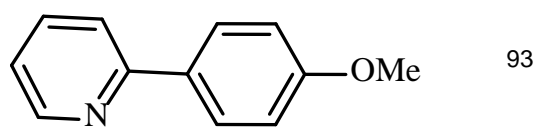


17<smiles>Brc1cncnc1</smiles>

18<smiles>O=[N+]([O-])c1ccc(Br)cc1</smiles>

19

20<smiles>N#Cc1ccc(Br)cc1</smiles>

22<smiles>O=[N+]([O-])c1ccc(Cl)cc1</smiles>

23<smiles>O=[N+]([O-])c1ccc(Cl)c([N+](=O)[O-])c1</smiles>

24<smiles>O=Cc1ccc(Cl)cc1</smiles>

25<smiles>N#Cc1ccc(Cl)cc1</smiles>

26<smiles>COc1ccc(I)cc1</smiles>

$\mathrm{MeO} \longrightarrow \mathrm{B}(\mathrm{OH})_{2}$<smiles>COc1ccc(-c2cncnc2)cc1</smiles>

$\mathrm{PhBF}_{3} \mathrm{~K}$

$\mathrm{PhBF}_{3} \mathrm{~K}$

$\mathrm{PhBF}_{3} \mathrm{~K}$

$\mathrm{PhBF}_{3} \mathrm{~K}$

24<smiles>O=[N+]([O-])c1ccc(-c2ccccc2)cc1</smiles>

$\mathrm{PhB}(\mathrm{OH})_{2}$

24<smiles>O=[N+]([O-])c1ccc(-c2ccccc2)c([N+](=O)[O-])c1</smiles>
$95^{d}$

$\mathrm{PhB}(\mathrm{OH})_{2}$

24<smiles>O=Cc1ccc(-c2ccccc2)cc1</smiles>

$\mathrm{PhB}(\mathrm{OH})_{2}$

24<smiles>N#Cc1ccc(-c2ccccc2)cc1</smiles>

$\mathrm{PhB}(\mathrm{OH})_{2}$<smiles>COc1ccc(-c2ccccc2)cc1</smiles>

95

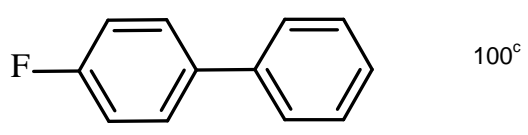


28<smiles>Clc1ccc(I)cc1</smiles>

29<smiles>Cc1ccc(N=[18O])cc1</smiles>

$\mathrm{PhB}(\mathrm{OH})_{2}$<smiles>Cc1ccc(N=[18O])cc1</smiles>

31<smiles>[123I-]Nc1ccccc1</smiles>

32<smiles>COc1ccc(N=[18O])cc1</smiles>

33<smiles>O=[N+]([O-])c1ccc(N=[18O])cc1</smiles>

$\mathrm{PhB}(\mathrm{OH})_{2}$

$\mathrm{PhB}(\mathrm{OH})_{2}$

$\mathrm{PhB}(\mathrm{OH})_{2}$

$\mathrm{PhB}(\mathrm{OH})_{2}$
4<smiles>Clc1ccc(-c2ccccc2)cc1</smiles>

3

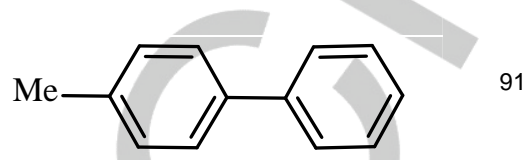<smiles>COc1ccc(Br)cc1</smiles>

3<smiles>COc1ccc(-c2ccc(C)cc2)cc1</smiles>

3

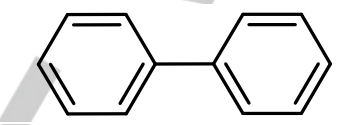

90

88

96

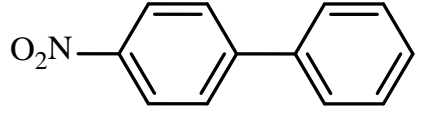

[a] Reaction conditions: $\operatorname{Ar}^{1} \mathrm{X}(0.5 \mathrm{mmol}), \mathrm{Ar}^{2} \mathrm{BR}(0.75 \mathrm{mmol}), t$-BuOK $(0.75 \mathrm{mmol}), \mathrm{EtOH}: \mathrm{H}_{2} \mathrm{O}(2 \mathrm{~mL}, 1: 1)$, catalyst Pd@CQD@Fe $\mathrm{O}_{4} \mathrm{NPs}(0.3 \mathrm{~mol} \% \mathrm{Pd})$ at $60{ }^{\circ} \mathrm{C}$

[b] Isolated yields

[c] GC yields

[d] Reaction conditions: $\mathrm{ArCl}(0.5 \mathrm{mmol}), \mathrm{ArB}(\mathrm{OH})_{2}(0.75 \mathrm{mmol}), \mathrm{KOH}(0.75 \mathrm{mmol}), \mathrm{PEG} 200(2 \mathrm{~mL})$, catalyst $\mathrm{Pd} @ \mathrm{CQD}_{0} @ \mathrm{Fe}_{3} \mathrm{O}_{4} \mathrm{NPs}(0.3 \mathrm{~mol} \% \mathrm{Pd})$ at $120{ }^{\circ} \mathrm{C}$.

In order to study the recycling properties of the catalyst, reduction of 4-nitrotoluene under optimized reaction conditions was studied. After completion of reaction, the catalyst was separated by an external magnet and after washing with diethyl ether and drying it was used in another batch of reaction. Results showed that this catalyst can be recovered and reused for 7 consecutive runs without significant decrease in activity (Figure 10). Also, the recycling ability of the catalyst was studied in the Suzuki reaction of 4-iodoanisole with phenylboronic acid under the optimized reaction conditions. Also in this case, the catalyst can be easily recycled, using an external magnet (Figure 3, ESI), during 10 consecutive runs with very small decrease in catalytic activity (Figure 10).

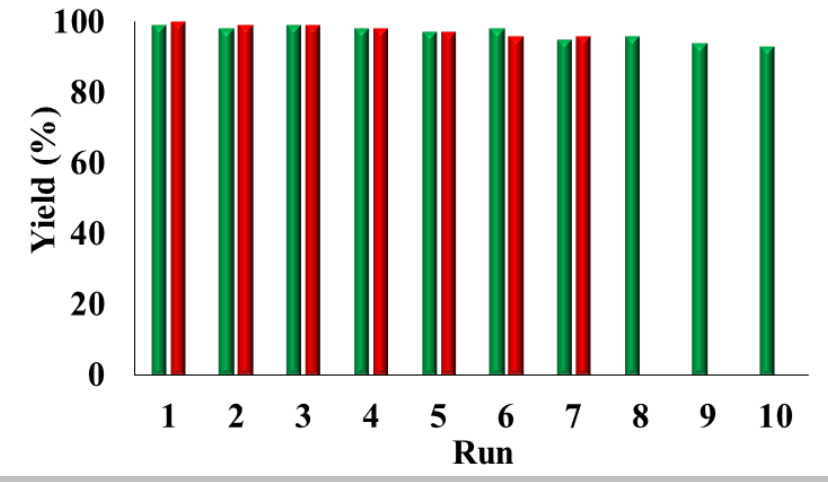


Figure 10. Recycling of the catalyst Pd@CQD@ $\mathrm{Fe}_{3} \mathrm{O}_{4} \mathrm{NPs}$ for the reduction of 4-nitrotoluene (red) and Suzuki reaction of 4-iodoanisole with phenylboronic acid (green).

TEM images of the reused catalyst after 10 runs showed that the structure was preserved and also the presence of the carbon quantum dot shell (Figure 11). Leaching of $\mathrm{Pd}$ and Fe from the

catalyst after 10 runs were found to be 16 and $0.2 \%$, respectively. These results confirm the strong ability of CQD for protection of $\mathrm{Fe}_{3} \mathrm{O}_{4}$ NPS and prevent their leaching and aggregation during the recycling processes. However, XPS study of reused catalyst after the $3^{\text {rd }}$ run showed that all palladium species are excited in reduced $\mathrm{Pd}(0)$ form (Figure 12). Study of magnetization curve of reused catalyst showed that catalyst preserve its superparamagnetic properties with very small decrease of magnetization (Figure 8). Also, the nitrogen adsorption-desorption isotherms for Pd@CQD@ $@ \mathrm{Fe}_{3} \mathrm{O}_{4} \mathrm{NPS}$ showed preservation of the structure with similar diagram than the fresh catalyst (Figure 4, ESI). In addition, these results indicated $v_{p}=0.30 \mathrm{~cm}^{3} \mathrm{~g}^{-1}$ and $r_{p}=4.61 \mathrm{~nm}$ for the recycle catalyst which is maybe due to damaging of walls of caves during the washing and recycling of the catalyst (Figure 5, ESI).

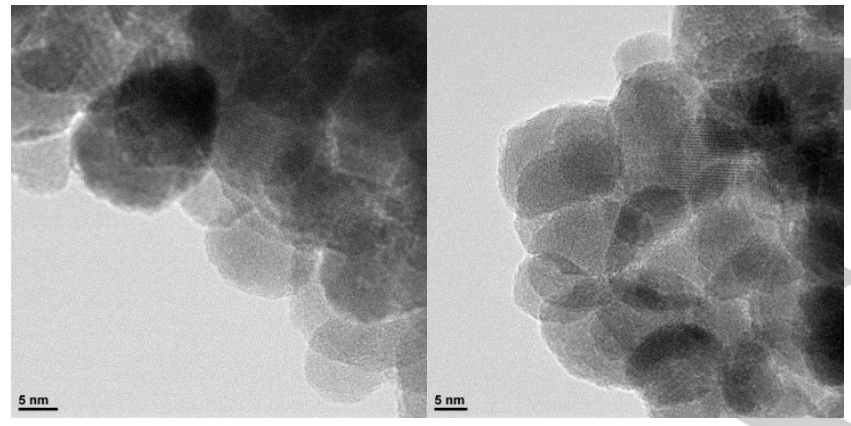

Figure 11. TEM image of reused catalyst after the $10^{\text {th }}$ run for the reaction of 4-iodoanisole with phenylboronic acid.

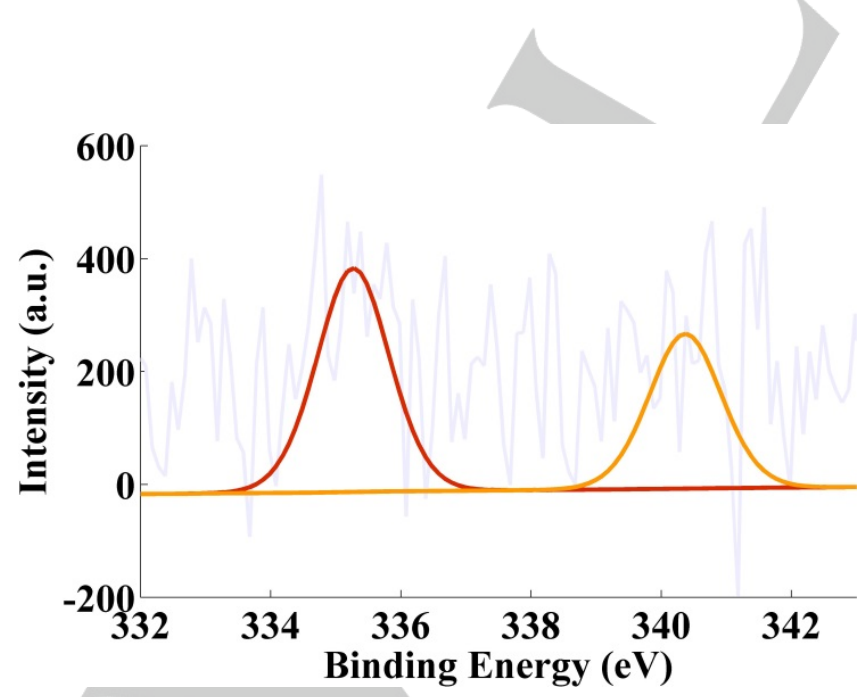

Figure 12. XPS spectrum of reused Pd catalyst in $3 d$ region for the reaction of 4-iodoanisole with phenylboronic acid after $3^{\text {rd }}$ run

To understand whether the presented catalyst is worked under heterogeneous pathway, or proceeds using leached $\mathrm{Pd}$, we studied hot filtration test for the reaction of 4bromobenzaldehyde with phenylboronic acid under the optimized reaction conditions. During this test, the catalyst was stirred in the reaction solvent $\left(\mathrm{H}_{2} \mathrm{O}-\mathrm{EtOH}\right)$ for $30 \mathrm{~min}$ at $60{ }^{\circ} \mathrm{C}$. Then, the catalyst was removed by filtration and 4bromobenzaldehyde, phenylboronic acid and $t$-BuOK were added and the resulting mixture was allowed to react. After $2 \mathrm{~h}$, GC analysis of reaction showed the formation of $25 \%$ of the desired coupling product and $75 \%$ of 4 -bromobenzaldehyde. It should be noted that a positive hot filtration test interpreted as proof for homogeneous catalysis, whereas a negative hot filtration test does not necessarily indicate the emergence of heterogeneous catalysis due to possibility of fast deactivation or redeposition of soluble active species. Furthermore, using solely hot filtration test for detection of heterogeneous toward homogeneous catalysis is not sufficient and further experiments are needed for finding the nature of the catalyst. ${ }^{[25]}$ In order to gain more insight on the behavior of the catalyst in the reaction, we added poly(vinylpyridine)(PVPy $2 \%$ cross-linked) as an efficient poising agent for soluble palladium species to the reaction mixture of 4-bromobenzaldehyde with phenylboronic acid with molar ratio of 100:1 (PVPy:Pd). Very interestingly, results showed that reaction was quenched without formation of product and starting material was intact. Also, addition of $\mathrm{SH} @ \mathrm{Fe}_{3} \mathrm{O}_{4}$ obtained from modification of $\mathrm{Fe}_{3} \mathrm{O}_{4}$ NPs with 3mercaptopropyl trimethoxysilane, showed complete suppression of activity. ${ }^{[25]}$ Another method for detection of homogeneous systems from heterogeneous is inverse relationship between the active $\mathrm{Pd}$ concentration and the conversion in homogeneous mechanisms. To investigate the effect of $\mathrm{Pd}$ concentration, reaction of 4-bromobenzaldehyde with phenylboronic acid using 0.3, 1 and 2 mol\% was studied. Results showed the formation of products in $92 \%, 90 \%$ and $78 \%$ GC yields, respectively. This reduction of reactivity in higher percentage of $\mathrm{Pd}$ catalyst is attributed to the formation of inactive Pd clusters from leached soluble Pd species. ${ }^{[26]}$

From the results of above experiments, we conclude that using this catalyst reactions proceed under release-return $\mathrm{Pd}(0)$ system in which leached active $\operatorname{Pd}(0)$ species catalyzed reaction and transfer of $\mathrm{Pd}$ between solvent and support is responsible for its recycling. ${ }^{[27]}$ These results are similar to obtained results by Arai et al. in which when a homogeneous Pd catalyst was used in the presence of additional support, the $\mathrm{Pd}$ species deposited on the support after the completion of the reaction. ${ }^{[2]}$

\section{Conclusions}

In conclusion, in this work we prepared modified $\mathrm{Fe}_{3} \mathrm{O}_{4} \mathrm{NPs}$ by CQD obtained from glycerol and urea as cheap and green starting materials. The new magnetic compound can reduce $\mathrm{Pd}(\mathrm{II})$ to $\mathrm{Pd}(0)$ and the obtained catalyst Pd@CQD@ $\mathrm{Fe}_{3} \mathrm{O}_{4} \mathrm{NPs}$ 
showed high activity in the selective reduction of nitroarenes and the Suzuki cross-coupling reaction. This magnetically recyclable catalyst was reused for several times in both reactions without significant loss of activity and the fresh and recovered catalysts were characterized by different analysis. Nature of true catalyst in Suzuki reaction was also determined by different tests to be homogeneous system.

\section{Experimental Section}

\section{Synthesis of $\mathrm{Fe}_{3} \mathrm{O}_{4}$ nanoparticles (MNPs):}

$\mathrm{FeCl}_{3} \cdot 6 \mathrm{H}_{2} \mathrm{O}(16 \mathrm{mmol}, 4.32 \mathrm{~g})$ and $\mathrm{FeCl}_{2} \cdot 4 \mathrm{H}_{2} \mathrm{O}(8 \mathrm{mmol}, 1.59 \mathrm{~g})$ were dissolved in deionized water $(250 \mathrm{~mL})$ under argon atmosphere and vigorous mechanically stirring. Then, aqueous ammonia $(25 \%, 13 \mathrm{~mL})$ was added slowly under argon atmosphere and the resulting mixture was stirred at $80{ }^{\circ} \mathrm{C}$ for $4 \mathrm{~h}$. The black magnetic precipitates were separated by an external magnet and washed several times with deionized water and ethanol and dried in a vacuum oven at $60{ }^{\circ} \mathrm{C}$ for $24 \mathrm{~h}$ to give the black MNPs.

\section{Synthesis of $\mathrm{Fe}_{3} \mathrm{O}_{4} @ \mathrm{CQD}$ :}

The CQD used in our experiments were synthesized by carbonization of glycerol and urea. A solution of glycerol $(12.5 \mathrm{~mL})$ and urea $(1 \mathrm{~g})$ in distilled water $(10 \mathrm{~mL})$ was stirred at room temperature for 10 min and then resulting mixture was heated in a Teflon autoclave at $180^{\circ} \mathrm{C}$ for $4 \mathrm{~h}$. Then, the mixture was cooled to room temperature and the obtained material was centrifuged at $10000 \mathrm{rpm}$ for $10 \mathrm{~min}$ to remove larger particles. After centrifugation the viscous oil was transferred to a $25 \mathrm{~mL}$ flask containing $\mathrm{Fe}_{3} \mathrm{O}_{4} \mathrm{NPs}\left(500 \mathrm{mg}\right.$ in $10 \mathrm{~mL} \mathrm{H} \mathrm{H}_{2} \mathrm{O}$ ) and the mixture sonicated for $15 \mathrm{~min}$. Then, this mixture was stirred using mechanical stirrer at $80{ }^{\circ} \mathrm{C}$ for $48 \mathrm{~h}$. Resulting $\mathrm{CQD} @ \mathrm{Fe}_{3} \mathrm{O}_{4}$ was subjected to magnetic separation and the obtained material was washed with deionized water $(3 \times 20 \mathrm{~mL})$ and ethanol $(3 \times 20 \mathrm{~mL})$ and dried under vacuum.

\section{Synthesis of Pd@CQD@Fe $\mathrm{O}_{4}$ :}

In a $50 \mathrm{~mL}$ flask, CQD@ $\mathrm{Fe}_{3} \mathrm{O}_{4}(1 \mathrm{~g})$ was sonicated in $\mathrm{H}_{2} \mathrm{O}(7 \mathrm{~mL})$ for 10 min. In another batch, $\mathrm{PdCl}_{2}(20 \mathrm{mg}, 0.11 \mathrm{mmol})$ was sonicated and dissolved in $\mathrm{H}_{2} \mathrm{O}(3 \mathrm{~mL})$ and the resulting solution was added slowly to the flask containing $\mathrm{CQD} @ \mathrm{Fe}_{3} \mathrm{O}_{4}$ under argon atmosphere and the mixture stirred at $60^{\circ} \mathrm{C}$ for $24 \mathrm{~h}$. Then, the resultant solids were collected by magnetic force, followed by washing with $\mathrm{H}_{2} \mathrm{O}(2 \times 10 \mathrm{~mL})$ and EtOH $(2 \times 10 \mathrm{~mL})$ and dried under vacuum at $70^{\circ} \mathrm{C}$.

\section{General procedure for the catalytic reduction of nitro compounds:}

Nitroarene $(0.5 \mathrm{mmol}), \mathrm{NaBH}_{4}$ (2 eq), catalyst $(0.008 \mathrm{~mol} \% \mathrm{Pd})$, and $\mathrm{H}_{2} \mathrm{O}$ :ethanol $(5: 1,2 \mathrm{~mL})$ were added to a $5 \mathrm{~mL}$ flask and stirred for appropriate reaction time at room temperature. Progress of the reactions was monitored by $\mathrm{GC}$ analysis. After completion of the reaction, crude product was extracted by ethyl acetate $(3 \times 5 \mathrm{~mL})$ and purified using column or plate chromatography.

\section{General procedure for the Suzuki-Miyaura reaction:}

Aryl halide or arenediazonium salts $(0.5 \mathrm{mmol})$, arylborane compound (0.75 mmol), base $(0.75 \mathrm{mmol})$, catalyst Pd@CQD@ $\mathrm{Fe}_{3} \mathrm{O}_{4} \mathrm{NPs}(0.3$ mol\% Pd) and solvent ( $2 \mathrm{~mL}$ of aqueous ethanol or PEG 200) were added to a $5 \mathrm{~mL}$ flask, and the mixture was stirred mechanically at appropriate temperature $\left(60-120{ }^{\circ} \mathrm{C}\right.$, see Tables). The progress of the reaction was monitored by GC or TLC. After completion of the reaction, the crude product was extracted using ethyl acetate or dichloromethane. The pure products were obtained by column or TLC plate chromatography on silica gel.

Typical recycling procedure for the reaction of 4-iodanisole with phenylboronic acid:

After completion of the reaction which was monitored by GC analysis, the catalyst was separated by external magnet. Then, separated catalyst was washed with diethyl ether and after drying was used in another batch of the reaction. This process was repeated for 10 consecutive runs. Similar process has been applied for the recycling of catalyst in reduction reaction.

\section{Acknowledgements}

The authors are grateful to Institute for Advanced Studies in Basic Sciences (IASBS) Research Council and Iran National Science Foundation (INSF-Grant number of 95844587) for support of this work. C. Nájera is also thankful for financial support to the Spanish Ministerio de Economía y Competitividad (MINECO) (projects CTQ2013-43446-P and CTQ2014-51912REDC), the Spanish Ministerio de Economía, Industria y Competitividad, Agencia Estatal de Investigación (AEI) and Fondo Europeo de Desarrollo Regional (FEDER, EU) (projects CTQ2016-76782-P and CTQ2016-81797-REDC), the Generalitat Valenciana (PROMETEOII/2014/017) and the University of Alicante

Keywords: Magnetic $•$ Palladium•Suzuki•Carbon quantum dots•Glycerol

[1] P. Tundo, P. Anastas, D. StC. Black, J. Breen, T. Collins, S. Memoli, J. Miyamoto, M. Polyakoff, W. Tumas, Pure Appl. Chem. 2000, 72, 12071228

[2] R. Schologl, Angew. Chem. Int. Ed. 2015, 54, 3465-3520.

[3] a) L. Yin, J. Liebscher, Chem. Rev. 2007, 107, 133-173; b) M. Lamblin L. Nassar-Hardy, J. C. Hierso, E. Fouquet, F. X. Felpin, Adv. Synth Catal. 2010, 352, 33-79; c) M. Mora, C. Jimenez-Sanchidrian and J. R. Ruiz, Curr. Org. Chem. 2012, 16, 1128-1150; d) L. Djakovitch and F. X. Felpin, ChemCatChem 2014, 6, 2175-2187.

[4] C. E. Garrett, K. Prasad, Adv. Synth. Catal. 2004, 346, 889-900.

[5] a) M. O. Sydnes, Catalysts 2017, 7, 35-49; b) I. Sarvi, M. Gholizadeh, M. Izadyar, Catal Lett. 2017, 147, 1162-1171; c) D. Wang, C. Deraedt, L. Salmon, C. Labrugere, L. Etienne, J. Ruiz, D. Astruc, Chem. Eur. J. 2014, 21, 1508-1519; d) F. Parra da Silva, L. Marcia Rossi, Tetrahedron 2014, 70, 3314-3318; e) B. Karimi, F. Mansouri, H. Vali, Green Chem. 2014, 16, 2587-2596; f) S. Verma, D. Verma, A. K. Sinha, S. L. Jain, Appl. Catal. A 2015, 489, 17-23; g) S. Rezaei, A. GhorbaniChoghamarani, R. Badri, Appl. Organomet. Chem. 2016, 30, 985-990; h) H. Veisi, J. Gholami, H. Ueda, P. Mohammadi, M. Noroozi, J. Mol. Catal. A: Chem. 2015, 396, 216-223; i) T. H. Rehm, A. Bogdan, C. Hofmann, P. Lob, Z. B. Shifrina, D. G. Morgan, L. M. Bronstein, ACS 
Appl. Mater. Interfaces 2015, 7, 27254-27261; j) P. Heidaria, R. Cheraghalia, H. Veisi, Appl. Organometal. Chem. 2016, 28, 868-873; k) F. Heidari, M. Hekmati, H. Veisi, J Colloid Interface Sci. 2017, 501, 175184; I) M. Hajighorbani, M. Hekmati, RSC Adv. 2016, 6, 88916-88924 m) M.Aghayee, M. A. Zolfigol, H. Keypour, M. Yarie, L. Mohammadi, Appl. Organomet. Chem. 2016, 30, 612-618; n) A. Pourjavadi, A Motamedi, Z. Marvdashti, S.H. Hosseini, Catal. Commun. 2017, 97, $27-$ 31; o) M. pirhayati, H. Veisi, A. Kakanejadifard, RSC Adv. 2016, 6 27252-27259; p) P. Yang, R. Ma, F. Bian, ChemCatChem 2016, 8 3746-3754; q) E. Rafiee, A. Ataei, M. Joshaghani, Tetrahedron Lett 2016, 57, 219-222.

[6] a) H. Min, S. Lee, M. Park, J. Hwang, H. M. Jung, S. Lee, J. Organomet Chem. 2014, 755, 7-11; b) H. S. Wang, Y. C. Wang, Y. M. Pan, S. L. Zhao, Z. F. Chen, Tetrahedron Lett. 2008, 49, 2634-2637; c) B. S. Kumar, A. J. Amali, K. Pitchumani, J. Mol. Catal. A: Chem. 2016, 423 511-519; d) R. J. Rahaim Jr, R. E. Maleczka, Synthesis 2006,19, 33163340; e) M. L. Kantam, R. Chakravarti, U. Pal, B. Sreedhar, S. Bhargava, Adv. Synth. Catal. 2008, 350, 822-827; f) A. Kumar, K. Purkait, S. K. Dey, A. Sarkar, A. Mukherjee, RSC Adv. 2014, 4, 3523335237; g) M. Shokouhimehr, T. Kim, S. W. Jun, K. Shin, Y. Jang, B. H. Kim, T. Hyeon, Appl. Catal. A. 2014, 476, 133-139; h) M. Demirelli, E. Karaoğlu, A. Baykal, H. Sözeri, E. Uysal, J. Alloys Compd. 2014, 582 201-207; i) J. Feng, S. Handa, F. Gallou, B. H. Lipshutz, Angew. Chem. Int. Ed. 2016, 55, 8979-8983; j) D. Rambabu, C. P. Pradeep, A. Dhir New J. Chem. 2015, 39, 8130-8135; k) H. Göksu, New J. Chem. 2015 39, 8498-8504; I) N. Mei, B. Liu, Int. J. Hydrogen Energy 2016 41,17960-17966; m) M. Nasrollahzadeh, S. M. Sajadi, A. RostamiVartooni, M. Alizadeh, M. Bagherzadeh, J. Colloid Interface Sci. 2016 466, 360-368; n) A. B. Dongil, L. Pastor-Pérez, J. L. Fierro, N. Escalona, A. Sepúlveda-Escribano, Appl. Catal. A 2016, 513, 89-97; o) M. Shokouhimehr, Catalysts 2015, 5, 534-560; p) H. K. Kadam, S. G. Tilve RSC Adv. 2015, 5, 83391-83407; q)T. Jiang, S. Du, T. Jafari, W. Zhong, Y. Sun, W. Song, S. L. Suib, Appl. Catal. A 2015, 502, 105-113; r) P. Wang, H. Liu, J. Niu, R. Li, J. Ma, Catal. Sci. Tech. 2014, 4, 1333-1339; s) B. Karimi, F. Mansouri, H. Vali, ChemPlusChem 2015, 80, 17501759 .

[7] a) A. Suzuki, J. Organomet. Chem. 1999, 576, 147-168; b) M. Blangetti, H. Rosso, C. Prandi, A. Deagostino, P. Venturello, Molecules 2013, 18 1188-1213; c) F. Alonso, I. P. Beletskaya, M. Yus, Tetrahedron 2008, 64, 3047-3101; d) V. Polshettiwar, A. Decottignies, C. Len, A. Fihri, ChemSusChem 2010, 3, 502-522; e) D. A. Alonso, C. Nájera, Chem. Soc. Rev. 2010, 39, 2891-2902; f) R. Rossi, F. Bellina, M. Lessi, Adv. Synth. Catal. 2012, 354, 1181-1255; g) G. A.Molander, S. R Wisniewski, E. Etemadi-Davan, J. Org. Chem. 2014, 79, 11199-11204.

[8] a) Y. Wang, A. Hu, J. Mater. Chem. C. 2014, 2, 6921-6939; b) S. Ying Lim, W. Shen, Z. Gao, Chem. Soc. Rev. 2015, 44, 362-381.

[9] D. Chowdhury, N. Gogoi, G. Majumdar, RSC Adv. 2012, 2, 1215612159.
[10] A. Prasannan, T. Imae, Ind. Eng. Chem. Res. 2013, 44, 15673-15678.

[11] P. C. Hsu, Z. Y. Shih, C. H. Lee, H. T. Chang, Green Chem. 2012,14, 917-920.

[12] A. Sachdev, P. Gopinath, Analyst 2015, 140, 4260-4269.

[13] V. Ramanan, S. K. Thiyagarajan, K. Raji, R. Suresh, R. Sekar, P. Ramamurthy, ACS Sustainable Chem. Eng. 2016, 4, 4724-4731

[14] C. W. Lai, Y. H. Hsiao, Y. K. Peng, P. T. Chou, J. Mater. Chem. 2012, 22, 14403-14409.

[15] D. Dey, T. Bhattacharya, B. Majumdar, S. Mandani, B. Sharma and T. K. Sarma, Dalton Trans. 2013, 42, 13821-13825.

[16] a) M. Gholinejad, M. Seyedhamzeh, M. Razeghi, C. Nájera, M Kompany-Zareh, ChemCatChem 2015, 80, 1573-1580; b) $M$ Gholinejad, M. Bahrami, C. Nájera, Molecular Catalysis 2017, 433, 12 19; c) M. Gholinejad, C. Najera, F. Hamed, M. Seyedhamzeh, M. Bahrami, M. Kompany-Zareh, Tetrahedron, 2017, Accepted, DOI: 10.1016/j.tet.2016.11.014; d) M. Gholinejad, J. Ahmadi, C. Najera, M. Seyedhamzeh, F. Zareh, and M. Kompany-Zareh, ChemCatChem 2017, 9, 1442-1449.

[17] R. Massart, IEEE Trans. Magn. 1981, 17, 1247-1248.

[18] S. Sahu, N. Sinha, S. K. Bhutia, M. Majhi, S. Mohapatra, J. Mater. Chem. B. 2014, 2, 3799-3808.

[19] R. Kannan, H. R. Jang, E. S. Yoo, H. K. Lee, D. J. Yoo, RSC Adv. 2015 5, 35993-36000

[20] a) M. Gholinejad, N. Jeddi, P. Biji, Tetrahedron 2016, 72, 2491-2500; b) M. Zhu, Y. Wang, C. Wang, W. Lia, G. Diao, Catal. Sci. Technol. 2013, 3, 952-961.

[21] W. Li, X. Jia, B. Zhang, L.Tian, X. Li, H. Zhang, Q. Zhang. New J. Chem. 2015, 39, 2925-2934.

[22] P. Luo, C. Li and G. Shi, Phys. Chem. Chem. Phys. 2012, 14, 7360 7366.

[23] A. Goyal, S. Kapoor, P. Samuel, V. Kumarc, S. Singhal, RSC Adv. 2015,5, 51347-51363

[24] a) N. Oger, F.-X. Felpin ChemCatChem 2016, 8, 1998-2009; b) A. Roglans, A. Pla-Quintana, and M. Moreno-Mañas, Chem. Rev. 2006, 106, 4622-4643.

[25] a) N. T. S. Phan, M. Van Der Sluys, C W. Jones. Adv. Synth. Catal. 2006, 348, 609-679; b) J. A. Widegren, R. G. Finke J. Mol. Catal. A Chem. 2003, 198, 317-341; c) B. Karimi, P. FadaviAkhavan, Inorg Chem. 2011, 50, 6063-6072.

[26] a) A. H. M. de Vries, J. M. C. A. Mulders, J. H. M. Mommers, H. J. W. Henderickx, J. G. de Vries Org. Lett. 2003, 5, 3285-3288; b) C. Deraedt, A. D. Didier Acc. Chem. Res. 2014, 47, 494-503; c) G. Collins, M. Schmidt, C. Dwyer, G. McGlacken, J. D. Holmes ACS Catal. 2014, 4, 3105-3111.

[27] A. Ohtaka , T. Okagaki, G. Hamasaka, Y. Uozumi, T. Shinagawa, O. Shimomura, R. Nomura Catalysts 2015, 5,106-118.

[28] F. Zhao, K. Murakami, M. Shirai, M. Arai. J. Catal. 2000,194, 479-483. 


\section{Entry for the Table of Contents}

Layout 1:

\section{FULL PAPER}

New sustainable magnetic-CQD supported palladium catalyst was prepared and applied in reduction and Suzuki reactions.
Mohammad Gholinejad, ${ }^{[a]}$ Fatemeh Zareh, ${ }^{[a]}$ Carmen Nájera* ${ }^{[b]}$

Page No. - Page No.

Nitro Group Reduction and Suzuki Reaction Catalyzed by Palladium Supported on Magnetic Nanoparticles Modified with Carbon Quantum Dots Generated from Glycerol and Urea 